\title{
STUDENTS' DIGITAL COMPETENCE: A SCOPING REVIEW OF MEASURING INSTRUMENTS
}

\author{
Sanita Litin,a, Anika Miltuze \\ University of Latvia, Latvia
}

\begin{abstract}
In today's society, digital competence is becoming increasingly relevant, as this competence is necessary to function on both a personal and professional level. Digital competence is essential for students, since it enables them to exist in a digitalised world. Over the last few decades, the concept of digital competence has been used more frequently (Spante et al., 2018), and now it is actively discussed, particularly in terms of policy documents (European Council, 2018; European Commission, 2014; European Commission 2021). During the discussions related to policy, the following questions have been raised: 1) what kind of skills and knowledge people should possess in a knowledge society, and 2) what should be taught to young students and how it has to be done (Ilomäki et al., 2016). The purpose of the present scoping review is to provide a comprehensive overview of relevant research regarding the instruments commonly used to measure digital competence of university students. Arksey and O'Malley's (2005) five-stage framework underpins the scoping review. Three databases were used to conduct a scoping literature review, including ERIC, ProQuest and EBSCO. The inclusion criteria were peer-reviewed publications written in English within the period from 2014 till 2020. Initially, 395 articles in total were selected; the full texts of 43 articles were assessed. Finally, only 13 out 395 articles that met the inclusion criteria were considered in the present research. This paper reports on three main categories: (1) definition of digital competence, (2) development and characteristics of an instrument measuring digital competence, and (3) key findings. The most commonly used framework found during this research was The European Digital Competence Framework for Citizens 2.0. (Vuorikari et al., 2016). A larger part of studies reports on a designed self-assessment questionnaire comprising of multiple-choice items and quantitative evaluation of the competence. The scoping review showed that the majority of the existing tests enable to assess students' digital information searching, communication and technical skills. The findings of previous studies indicate that students tend to overestimate their digital competence and lack knowledge of basic topics, the ones related to information and data literacy. Our findings point to the necessity to use different approaches for assessing digital competence on different levels.
\end{abstract}

Keywords: assessment instrument, digital competence, digital literacy,scoping review, student. 


\section{Introduction}

In the past decade, digital competence has become a key concept in the discussions about the activities that individuals should be able to do and the goals that should be achieved when using digital technologies (European Council, 2018). In higher education institutions and universities there is currently a high number of students who certainly have not experienced a moment without the presence of digital technology in most, if not all, aspects of their life (Maderick et al., 2016). It was estimated that, in broad terms, 72 per cent of households in urban areas had access to the Internet at home in 2019 , which is almost twice more than in rural areas, where only 38 per cent had access to the Internet (International Telecommunication Union, 2020). It implies that people, including students and educators, use different digital tools on the daily basis.

It has to be taken into account that during the COVID-19 crisis in spring 2020, various study courses and trainings were provided only in a digital environment, which was experienced for the first time by local students. Such condition has caused a need to focus on educators' and learners' digital competence. With the advent of digital technology, learning has been focused on processing the information received. Information and communication technology tools (ICT) have been used for various purposes, including searching, collecting and presenting information, communicating, collecting and processing data, simulating processes, as well as building new knowledge and creating products. A minimum set of digital skills is no longer enough to allow students to work effectively with digital tools, access the Internet or perform basic computer tasks (Buckingham, 2015). For this reason, enhancing digital competence is one of the priority objectives in education (European Commission, 2021, p. 6). Several different inventions have been applied to boost pupils' and students' motivation, so they could acquire the content of study courses more efficiently and qualitatively (Slavova \& Garov, 2019).

Digital competence is one of the eight key competencies for lifelong learning defined by the European Council of European Union (European Council, 2018, p.10) as "Digital competence involves the confident, critical and responsible use of, and engagement with, digital technologies for learning, at work, and for participation in society". Digital competence includes eight categories: information and data literacy, communication and collaboration, media literacy, digital content creation, safety, intellectual property issues, problem-solving and critical thinking (European Council, 2018).

In recent ten years there has been a growing interest in the assessment of digital competences and certification by various bodies, for example, 
education administrations, European Community, etc. (Stopar \& Bartol, 2019). Calvani working in collaboration with other colleagues managed to ascertain that the field of assessment of digital competence may be divided in different ways; the first is related to the possibility of obtaining information, that is, for a relatively short time; and the second may require repetition of observations over time to get more meaningful assessments of student involvement (Calvani et al., 2008).

The process of digital competence assessment is the complex one. Most of the examples of digital competence assessment that are reviewed in the Global Education Report: Creating Sustainable Futures For All (United Nations Educational, Scientific and Cultural Organization, 2016) involve computer-based performance assessments rather than assessments of knowledge about digital and ICT literacy.

In this scoping review, we are interested to summarizing and analysing the digital competence assessment tools explicitly used to assess students' digital skills.

\section{Defining digital literacy and digital competence}

Digital competence is essential for learning, work and active participation in a society. Over the past ten years the terms Digital competence and Digital literacy have become more widely used and more often discussed, especially in the field of policy documentation (European Commission, 2014; Eurydice, 2011). There have also been active discussions related to the types of skills and knowledge people need in a knowledge-based society, specifically what to teach and how to teach (Ilomäki et al., 2016).

The term Digital literacy was first introduced by Gilster as "the ability to understand and use information in multiple formats from a wide variety of sources when it is presented via computers" (1997, p. 6). Parvathamma and Pattar, in their turn, define digital literacy as the "ability to use ICT tools and internet access, manage, integrate, evaluate, create and communicate information to function in a knowledge society" (2013, p. 159).

Digital competence and digital literacy are often used synonymously (Krumsvik, 2008). Sometimes they are used to underpin each other, for instance as in Ferrari's report:

Digital Competence is the set of knowledge, skills, attitudes (thus including abilities, strategies, values, and awareness) that are required when using ICT and digital media to perform tasks; solve problems; communicate; manage information; collaborate; create and share content; as well as build knowledge effectively, efficiently, appropriately, critically, creatively, autonomously, flexibly, ethically, reflectively for work, leisure, participation, learning, socializing, consuming, and empowerment. (2012, p. 30) 
The concept of digital competence is a multi-faceted moving target covering many areas and literacies and rapidly evolving as new technologies appear. This way, Calvani and colleagues define digital competence as:

Digital competence consists of exploring and facing new technological situations flexibly, selecting and critically evaluating data and information, exploiting technical potentials to represent and solve problems, and building shared and collaborative knowledge while fostering awareness of one's responsibilities and the respect of reciprocal rights/obligations. (2008, p. 186)

Ferrari also highlights that the concept of digital competence is multifaceted, prone to continuous progress and rapid development, and is already influenced by the emergence of technology. According to Ferrari, to be digitally competent means to have the ability to understand media, to search and be critical about retrievable information, and to be able to communicate with others through a variety of digital tools and applications (Ferrari, 2012).

Digital competence can be understood as the ability to use technology effectively to improve performance in all areas of daily life. Several researchers suggest that digital competence is not just an isolated skill to be developed, but a range of skills, abilities, and attitudes to be deployed across different areas and dimensions of knowledge (Ferrari et al., 2014; Vázquez-Cano, 2014).

\section{Frameworks of digital competency}

According to the World Bank 2020 report Digital Skills: Frameworks and Programs, one of the most comprehensive and widely used frameworks for general digital skills is the European Union's European Digital Competence Framework for Citizens (DigComp) (Bashir \& Miyamoto, 2020). This framework has become a reference for strategical planning and development of digital competence initiatives at European and Member State levels. In 2013 the European Commission published the Digital Competence Framework (DigComp 1.0.). In June 2016 the European Commission Joint Research Center (JRC) published DigComp 2.0., updating the terminology and conceptual model (Vuorikari et al., 2016). In 2017 the Commission expanded it and published DigComp 2.1. which describes those competencies across eight proficiency levels, from foundation/beginner to highly specialized (Carretero et al., 2017). DigComp is subdivided into five areas and 21 competences, which include the notion of digital literacy (Ferrari, 2012).

From 2013 till now DigComp has been used extensively in the context of employment, education, as well as training and lifelong learning. The changes between the version of DigComp published between 2013 and 2017 
reflect certain developments such as an increased perception of "digital content" and "digital technologies," and include relevant updates regarding EU legislation, for example, The EU General Data Protection Regulation.

\section{Method}

A scoping review refers to the process of mapping or summarising the existing literature to understand the range of the field (Davis et al., 2009). A scoping study tends to present broader themes to which various types of study may be applicable and is less likely to seek to assess the quality of the studies included (Arksey \& O'Malley, 2005). To illustrate the search results of the study and to provide an overview of the inclusion and exclusion criteria, a scope review method was used; it is based on the framework of Arksey and O'Malley (2005). The method consists of five steps: "1) Identifying the research question; 2) Identifying relevant studies; 3) Study selection; 4) Charting the data; 5) Collating, summarizing, and reporting the results" (Arksey and O'Malley, 2005, p.22). A scoping review of studies, enabling us to describe instruments with the aim to assess digital competence, was conducted. A detailed description of inclusion and exclusion criteria is given in Table 1.

Table 1. Inclusion and exclusion criteria

\begin{tabular}{|l|l|l|}
\hline Criteria & Included & Excluded \\
\hline Time frame & 2014-2020 & Before 2014 and after 2020 \\
\hline Publication type & Online peer-reviewed articles & $\begin{array}{l}\text { Policy documents, books, } \\
\text { reports }\end{array}$ \\
\hline Focus & $\begin{array}{l}\text { Studies with a primary focus on } \\
\text { assessment or self- assessment of } \\
\text { digital competence }\end{array}$ & $\begin{array}{l}\text { Articles focusing on other } \\
\text { aspects }\end{array}$ \\
\hline Language & English & Other languages \\
\hline $\begin{array}{l}\text { Target } \\
\text { population }\end{array}$ & $\begin{array}{l}\text { Articles focusing on university } \\
\text { students and digital competence } \\
\text { assessment }\end{array}$ & $\begin{array}{l}\text { Articles focusing on pupils, } \\
\text { other population (seniors, } \\
\text { special needs, adults) }\end{array}$ \\
\hline
\end{tabular}

Eligibility criteria for final databases selection for this scoping review were the topic of interest, type of the article, and the accessibility of the databases.

Finally, scientific databases ERIC (Educational Resources Information Centre), ProQuest, EBSCO were included in this review of the scope literature. The research search was performed using only the following keywords: digital literacy, digital competence, digital competence assessment, assessing digital competence, student and assessment instrument. 


\section{Results}

The search generated 395 articles. All titles were analysed using the set inclusion criteria; 220 articles were excluded (Figure 1).

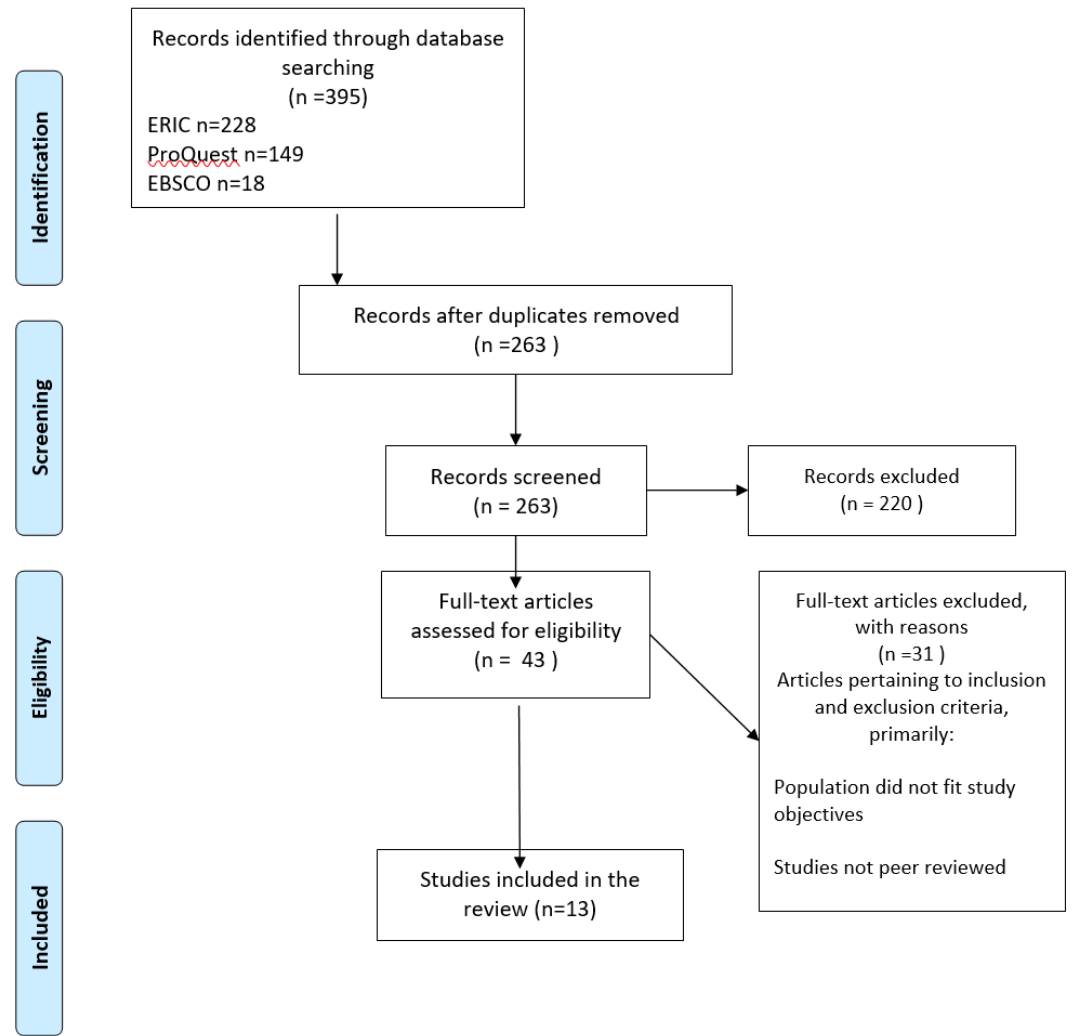

Figure 1. Flow diagramme for the scoping review search

The full texts of 43 articles were assessed. In the process of manual screening 30 of these articles were excluded, and 13 articles that met the inclusion criteria were included in the research (see Table 2). The exclusion on the studies was for two reasons: irrelevance of study objectives and absence of peer review.

Among the reviewed articles, 2 of them were from Spain, two - from Italy, and others - from Argentina, Chine, Chile, Colombia, Ecuador, Greece, Ireland, Japan, Peru, Poland, Slovakia, Ukraine and Venezuela. Eight of the total 13 articles reported were published within the last two years. This indicates that the research interest for digital competence assessment has increased. 
Table 2. Frameworks for Digital Competence

\begin{tabular}{|c|c|c|}
\hline Country & Author (Year) & $\begin{array}{l}\text { Theoretical / Conceptual } \\
\text { Framework }\end{array}$ \\
\hline $\begin{array}{l}\text { Argentina, } \\
\text { Colombia, Peru, and } \\
\text { Venezuela }\end{array}$ & $\begin{array}{l}\text { Crawford-Visbal et al. } \\
(2020)\end{array}$ & $\begin{array}{l}\text { European Framework of Digital } \\
\text { Competence 2.0., } 2016\end{array}$ \\
\hline Italy & Sciumbata (2020) & $\begin{array}{l}\text { European Framework of Digital } \\
\text { Competence Framework 2.0., } \\
2016\end{array}$ \\
\hline Ukraine & Kuzminska et al. (2019) & $\begin{array}{l}\text { European Framework of Digital } \\
\text { Competence 2.1., } 2017\end{array}$ \\
\hline Spain, Italy, Ecuador & Tejedor et al. (2020) & $\begin{array}{l}\text { Digital Competence Framework } \\
\text { for Educators, } 2017\end{array}$ \\
\hline $\begin{array}{l}\text { Greece, Ireland, } \\
\text { Scotland }\end{array}$ & Martzoukou et al. (2020) & $\begin{array}{l}\text { European Framework of Digital } \\
\text { Competence 2.1., } 2017 \\
\text { Digital capability framework } \\
\text { (JISC) }\end{array}$ \\
\hline China & He and Chang (2014) & $\begin{array}{l}\text { iDCA (instant digital } \\
\text { competence assessment) } \\
\text { instrument framework } \\
\text { (Calvani et al., 2008, 2012) }\end{array}$ \\
\hline Spain & $\begin{array}{l}\text { Vázquez-Cano et al. }(2017)^{1} ; \\
\text { Gutiérrez Porlán and } \\
\text { Sánchez Serrano }(2016)^{2} ; \\
\text { Esteve-Mon et al. }(2020)^{3} ; \\
\text { Guzmán-Simón et al. }(2017)^{4}\end{array}$ & $\begin{array}{l}1 \text { "University Students' Basic } \\
\text { Digital Competences 2.0" } \\
\text { (COBADI) } \\
\text { 2 European Framework of } \\
\text { Digital Competence 1.0. for } \\
\text { citizens, } 2013 \\
{ }^{3} \text { INCOTIC: Inventory of } \\
\text { Competencies in Information } \\
\text { and Communication } \\
\text { Technologies } \\
\text { INCOTIC questionnaire } \\
{ }^{4} \text { New Literacy Studies } \\
\text { approach (Barton \& Hamilton, } \\
\text { 1998; Baynham, 1995; Gee, } \\
\text { 1990; Street, 1995) }\end{array}$ \\
\hline Japan & Cote and Milliner (2016) & $\begin{array}{l}\text { Digital literacy questionnaire } \\
\text { adapted from a seminal } \\
\text { survey created by Son et al. } \\
(2011)\end{array}$ \\
\hline Poland, Slovakia & Hajduová et al. (2020) & $\begin{array}{l}\text { Authors develop an assessment } \\
\text { instrument }\end{array}$ \\
\hline Chile and Uruguay & Silva et al. (2019) & $\begin{array}{l}\text { Digital competence indicators } \\
\text { and dimensions proposed by } \\
\text { Lázaro and Gisbert (2015) }\end{array}$ \\
\hline
\end{tabular}


To identify the range of the study, article summaries with regard to the year of publication, country, purpose of the study, sample/participants, theoretical/conceptual framework, assessment instrument and key findings were provided (see Table 3).

Three types of data collection methods were identified, namely, self-assessment, performance-based assessment and test-type assessment. The digital competence framework consisting of six assessment instruments was based on DigComp assessment methodology, thus, it includes multiple-choice items. In the study by Tejedor and colleagues (2020) the design of the questionnaire was based on the Digital Competence Framework for Educators (DigCompEdu) (Redecker \& Punie, 2017). DigCompEdu is directed towards educators at all levels of education, from early childhood to higher and adult education, including general and vocational education and training, special needs education as well as non-formal learning contexts. In this scoping review, we also identified other digital competence assessment conceptual frameworks (see Table 2).

Four assessment instruments used a questionnaire based on a Likert type scale of digital competence, which represents different levels of skills. In one of the studies by Crawford-Visbal and colleagues (2020) qualitative communication methods were used: focus groups and semi-structured interviews were conducted to measure progress in digital competencies. In the study by Sciumbata (2020), participants answered the survey that consisted of four sections, including preliminary questions, two self-assessment parts and a section containing multiple-choice questions to test the actual knowledge of the participants. In their study, Gutiérrez Porlán and Sánchez Serrano (2016), basing on DigComp 1.0. methodology at the core of which there are statements divided into five blocks, two questionnaires were distributed to students, namely, a questionnaire onself-perception and on digital competence. The second questionnaire on digital competence was an adaption of the first one, since it included the following statement: "Task $\mathrm{X}$ has helped improve my competence in area X." that helped to get more profound understanding of the issues on the basis of students' responses (Gutiérrez Porlán \& Sánchez Serrano, 2016, p. 53)

Most of the tools consisted of several dimensions, categories, or areas of digital competence (see Table 3). 


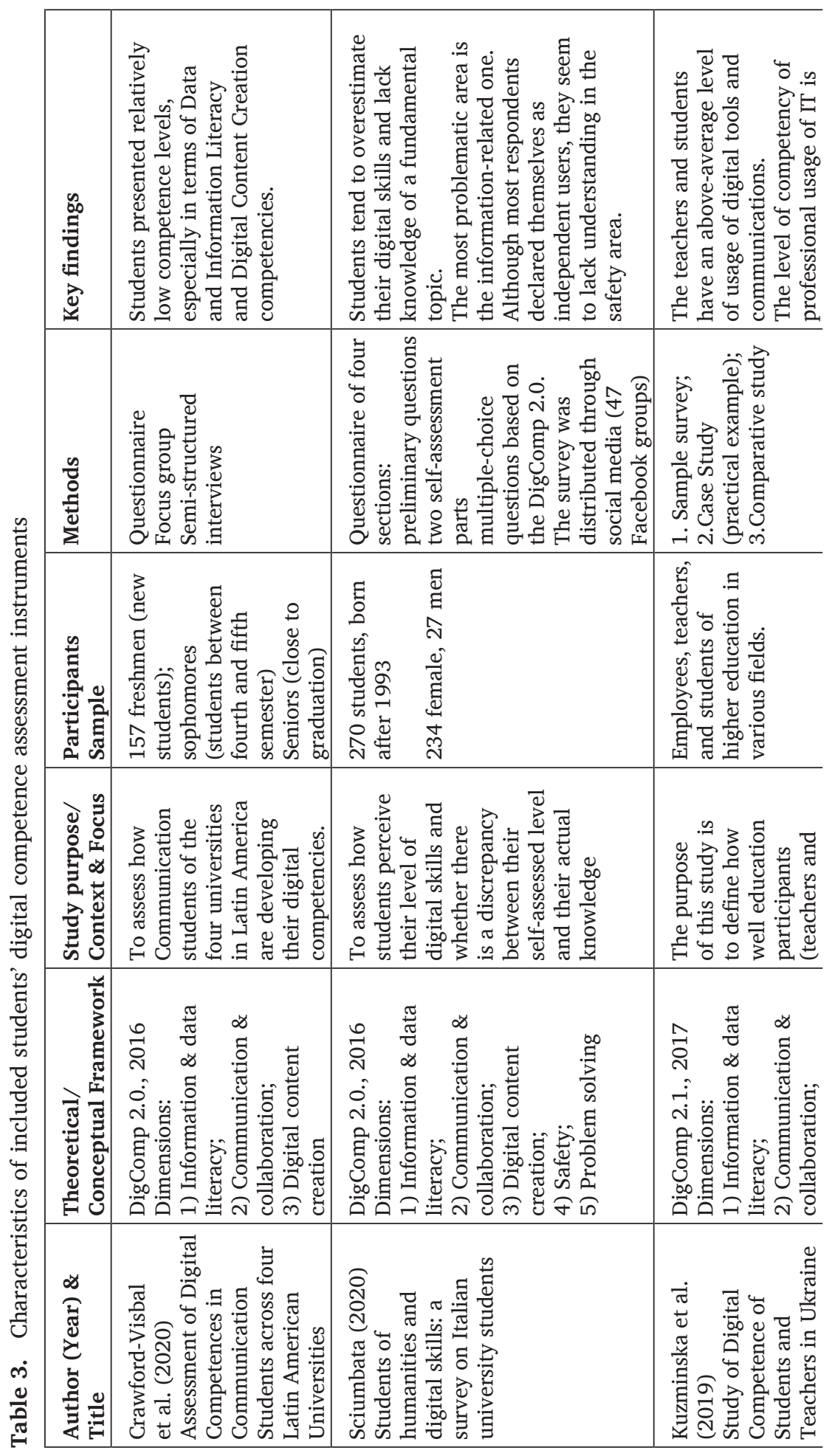




\begin{tabular}{|c|c|c|}
\hline \multirow[t]{3}{*}{ 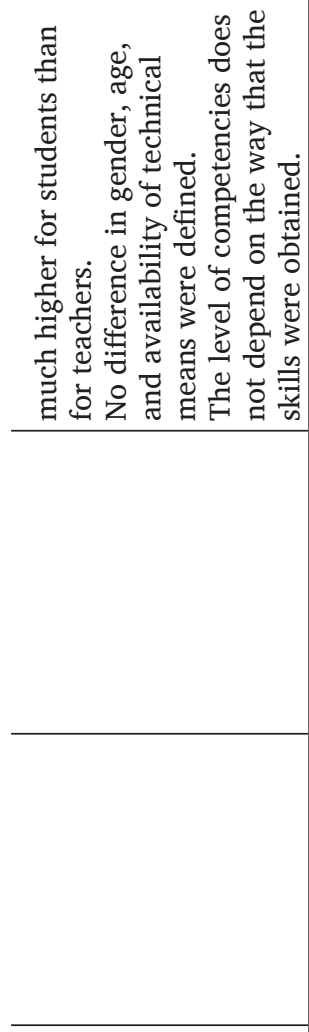 } & 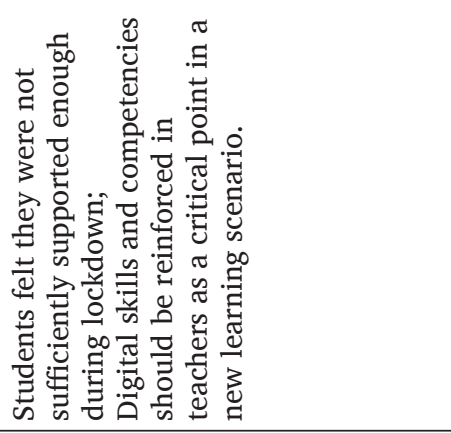 & 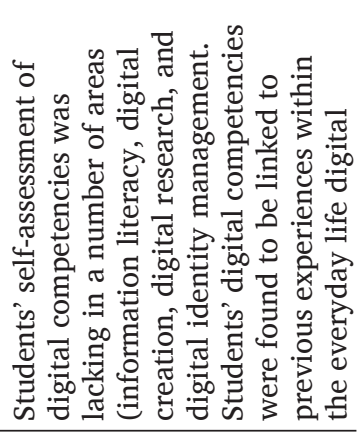 \\
\hline & 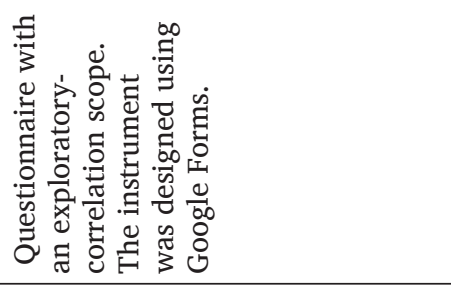 & 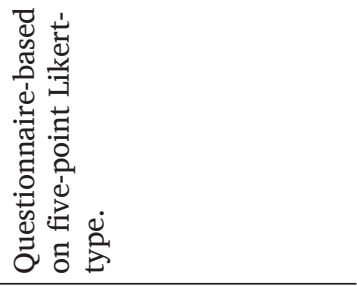 \\
\hline & 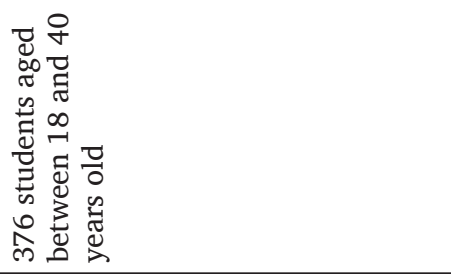 & 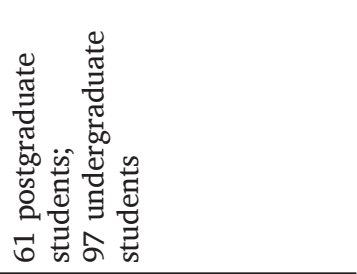 \\
\hline 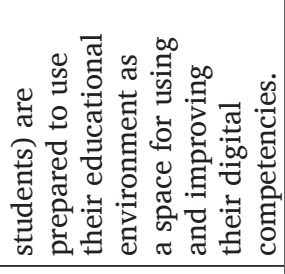 & 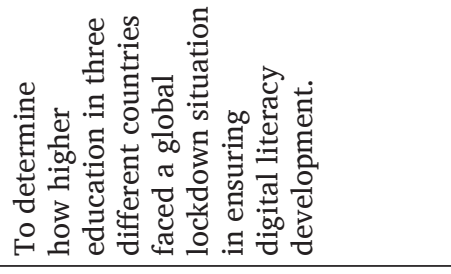 & 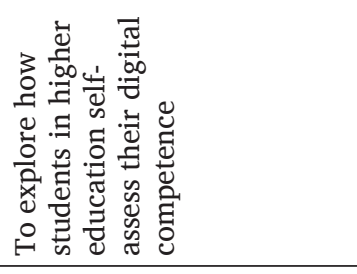 \\
\hline \multirow[t]{2}{*}{ 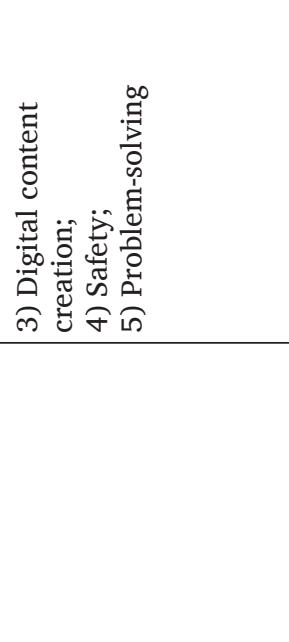 } & 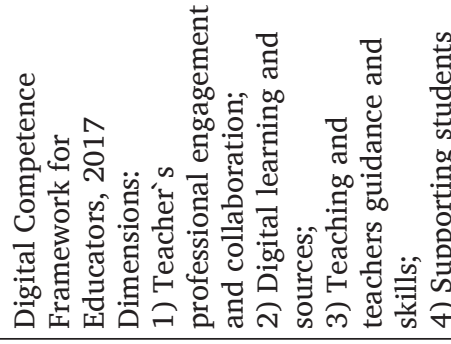 & 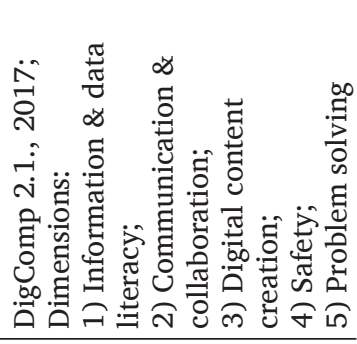 \\
\hline & 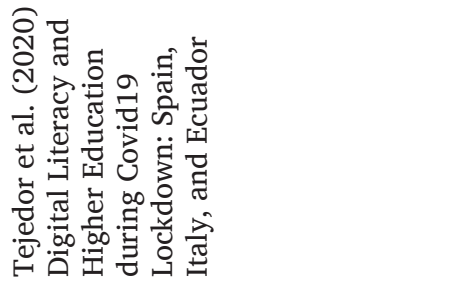 & 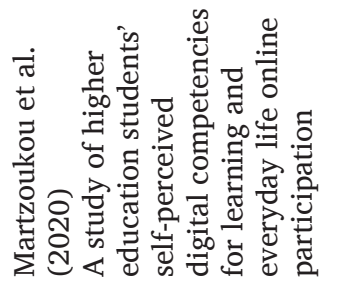 \\
\hline
\end{tabular}




\begin{tabular}{|c|c|}
\hline \multirow[t]{4}{*}{ 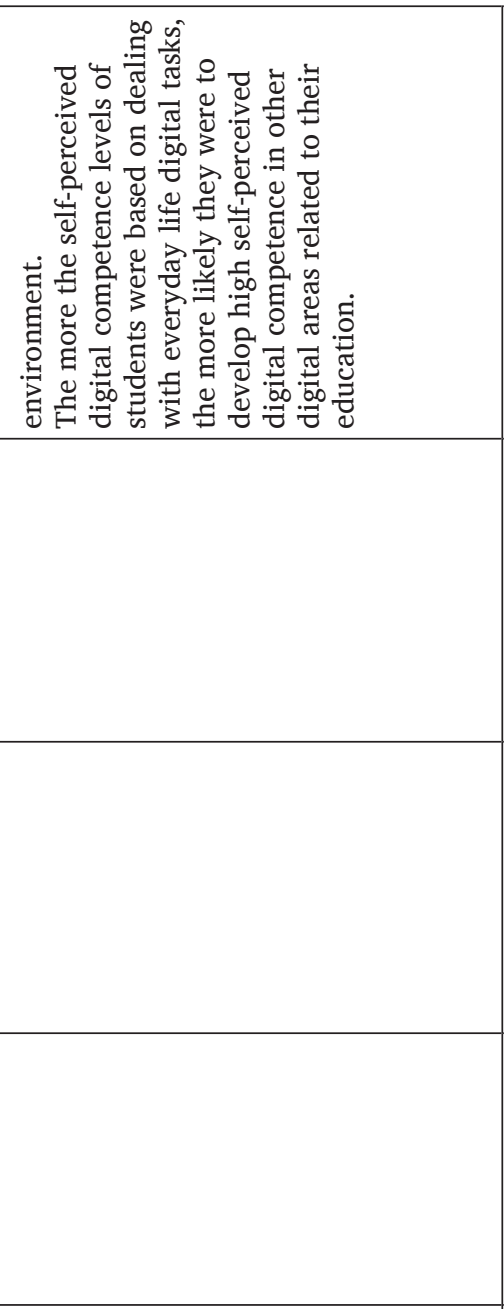 } & 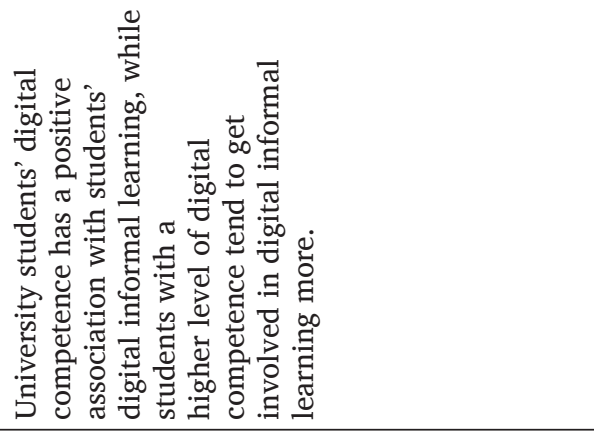 \\
\hline & 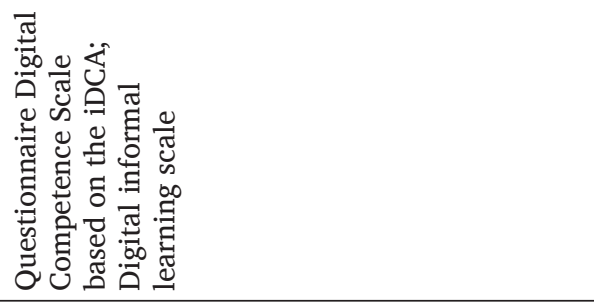 \\
\hline & 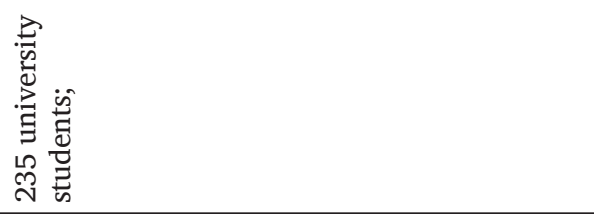 \\
\hline & 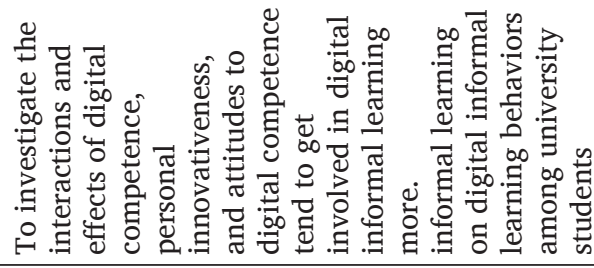 \\
\hline \multirow[t]{2}{*}{ 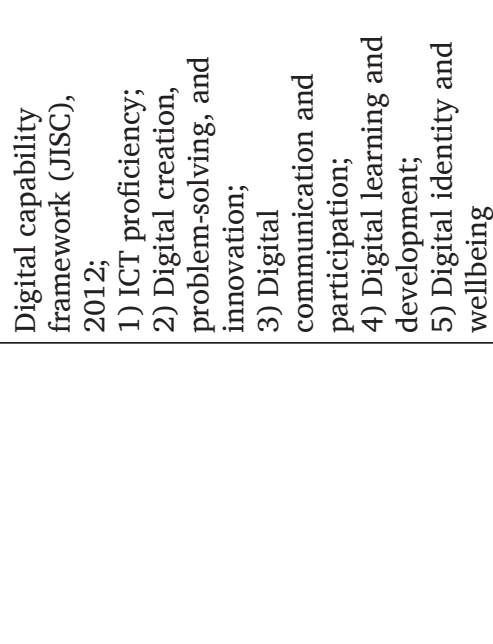 } & 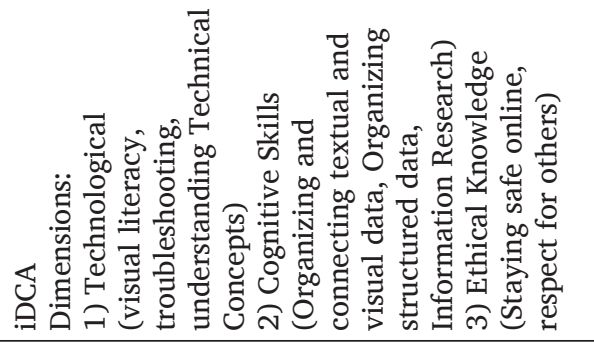 \\
\hline & 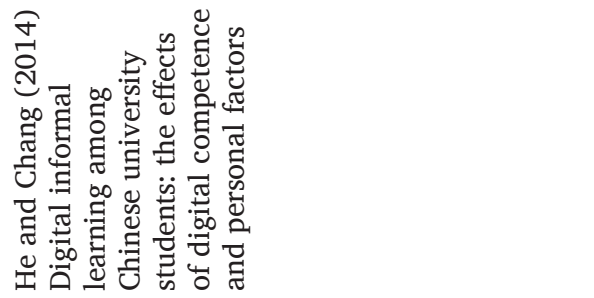 \\
\hline
\end{tabular}




\begin{tabular}{|c|c|}
\hline 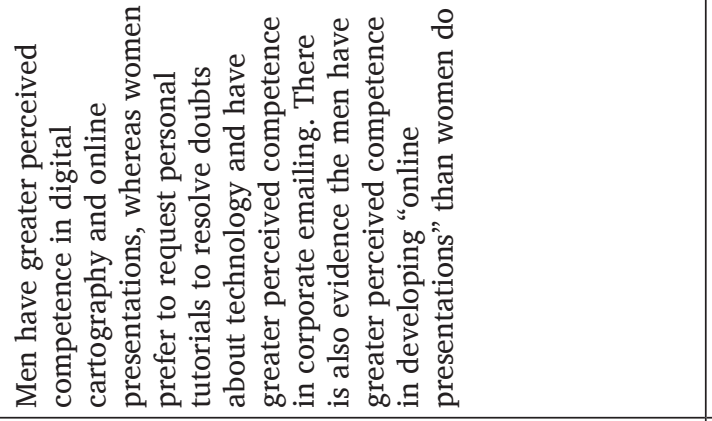 & 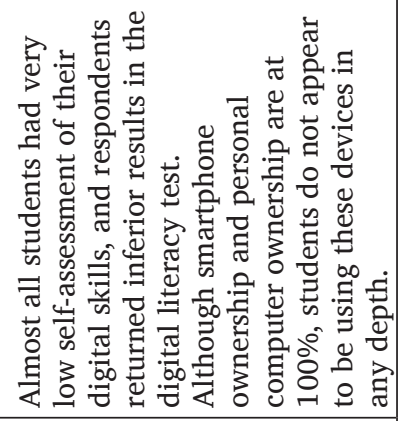 \\
\hline 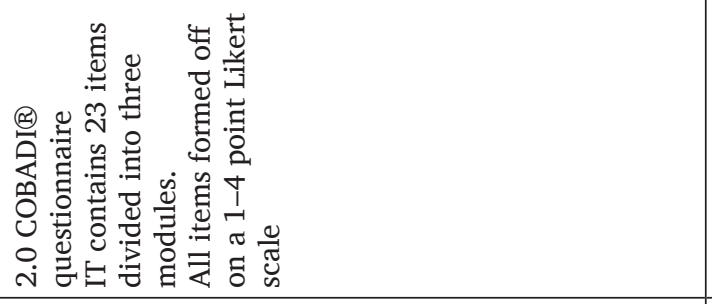 & 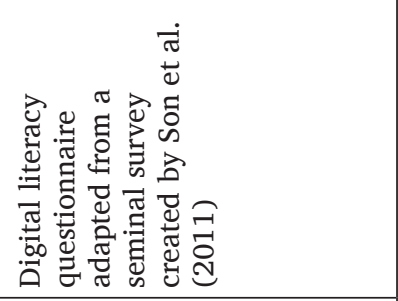 \\
\hline & 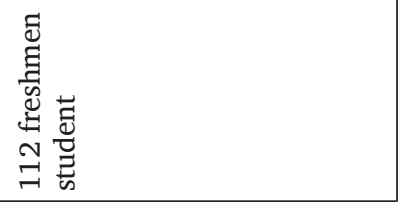 \\
\hline 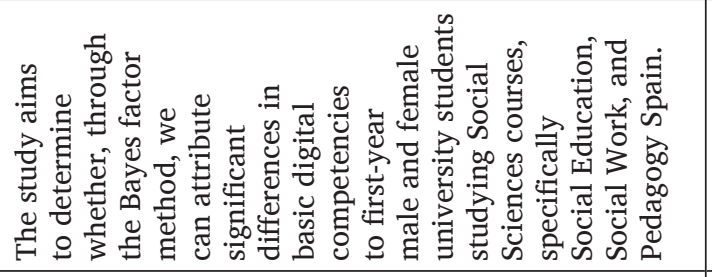 & 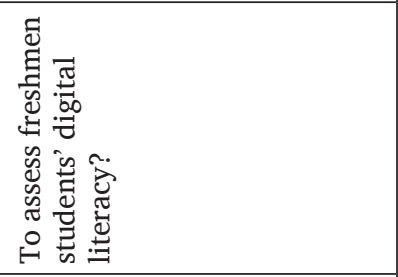 \\
\hline 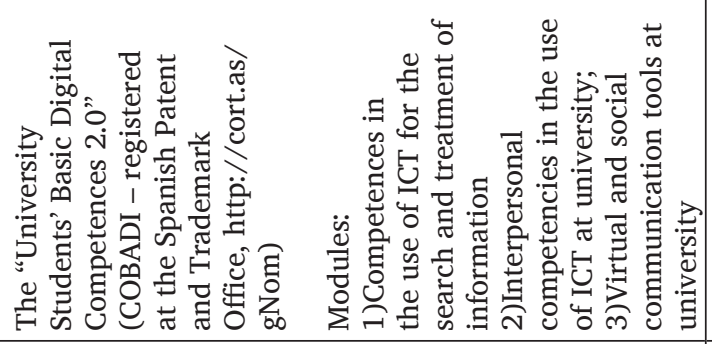 & 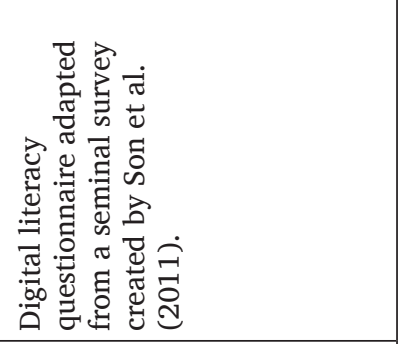 \\
\hline 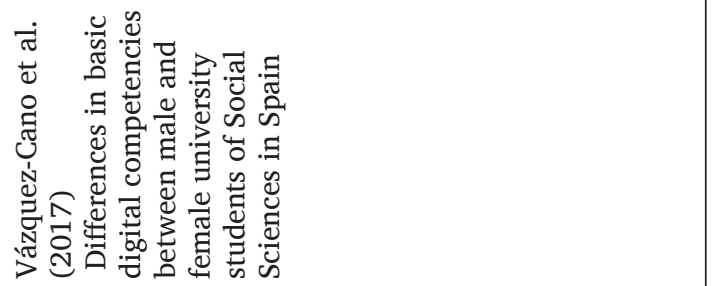 & 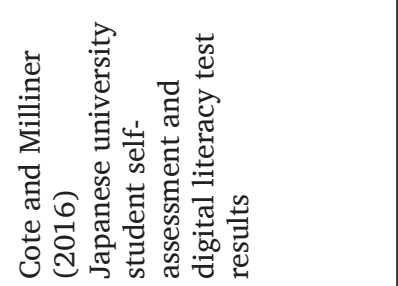 \\
\hline
\end{tabular}




\begin{tabular}{|c|c|c|}
\hline 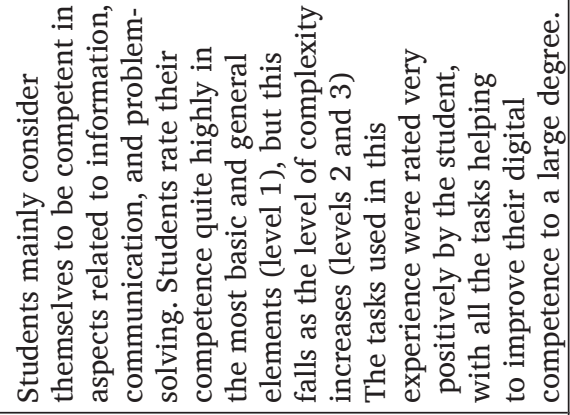 & 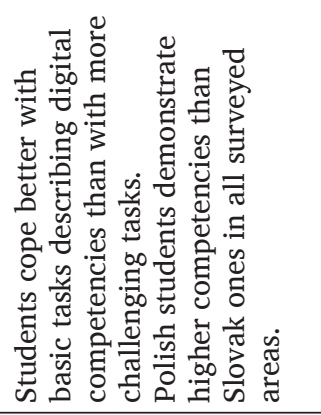 & 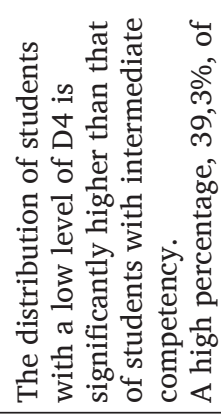 \\
\hline 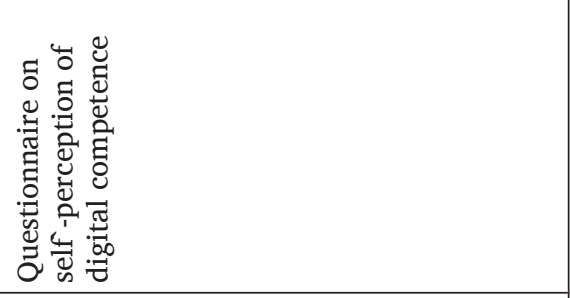 & 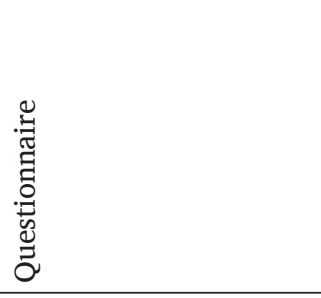 & 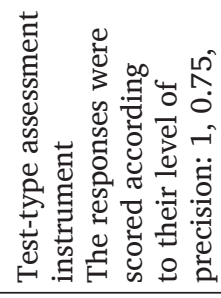 \\
\hline 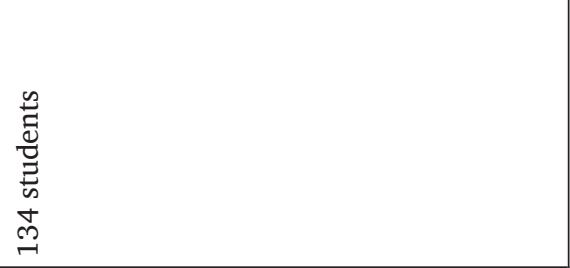 & 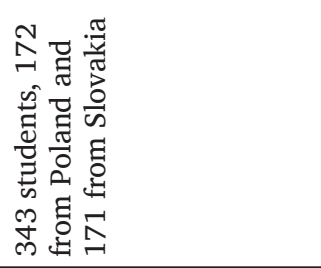 & 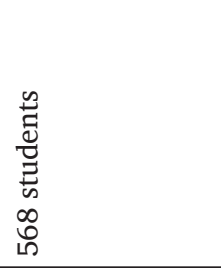 \\
\hline 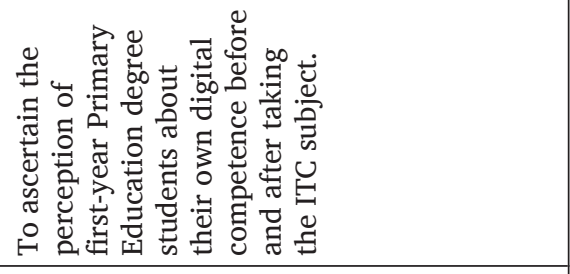 & 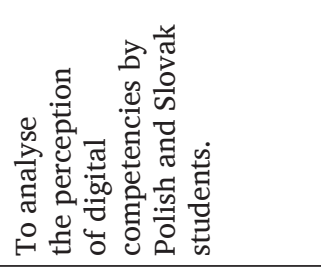 & 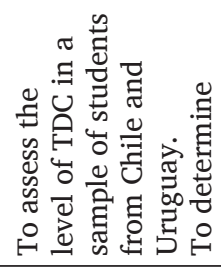 \\
\hline 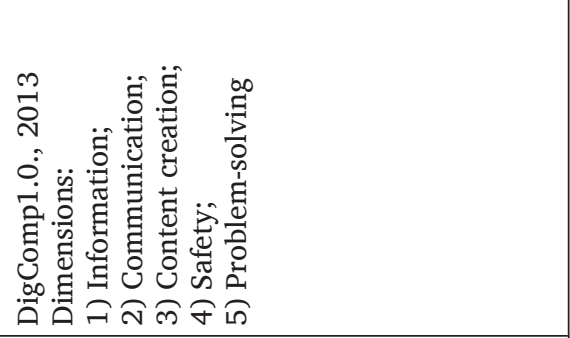 & 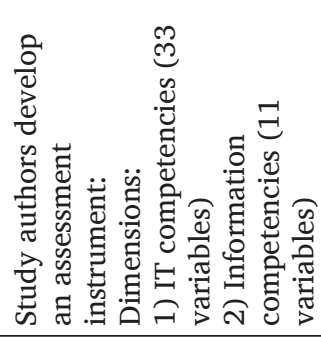 & 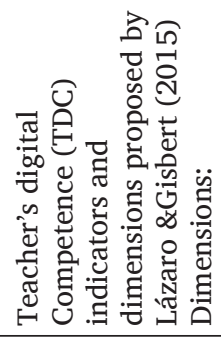 \\
\hline 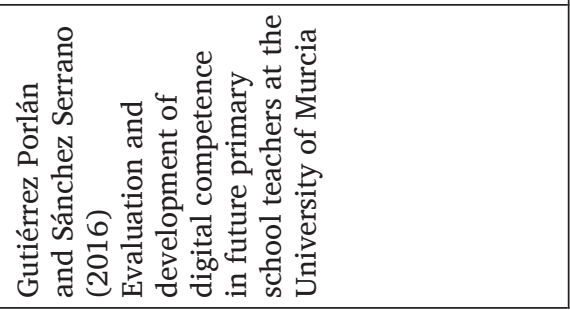 & 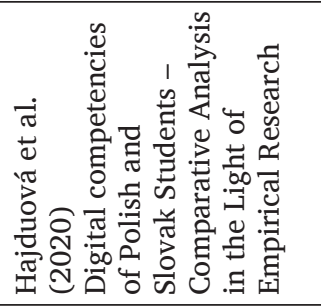 & 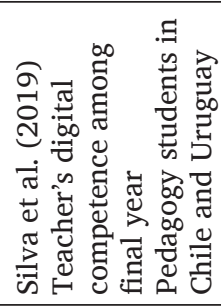 \\
\hline
\end{tabular}




\begin{tabular}{|c|c|}
\hline 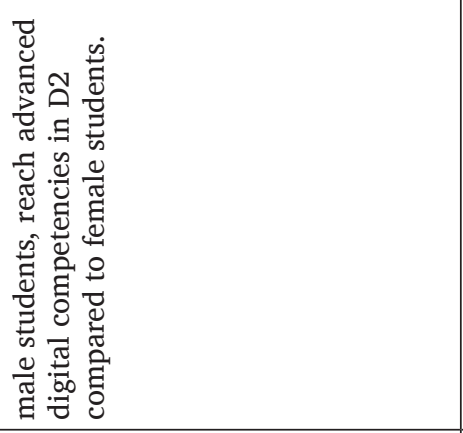 & 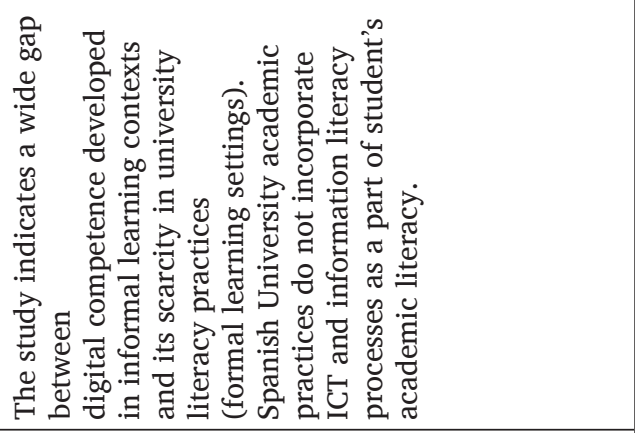 \\
\hline 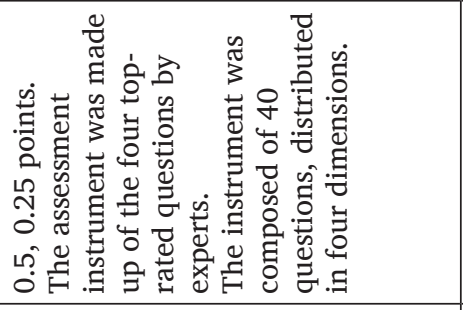 & 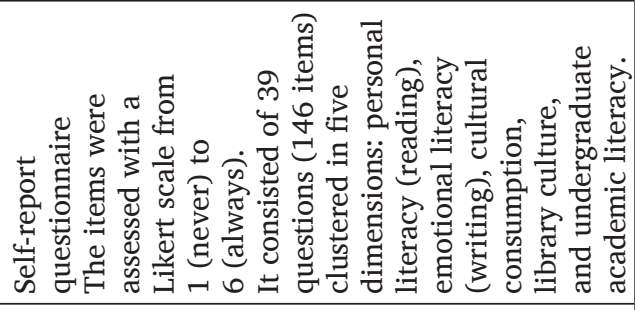 \\
\hline & 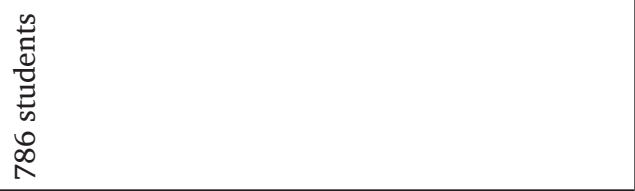 \\
\hline 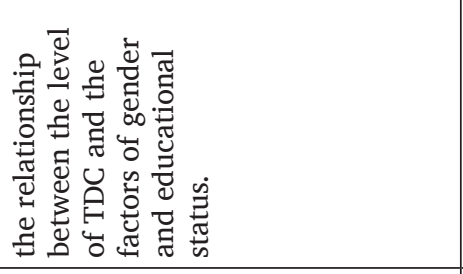 & 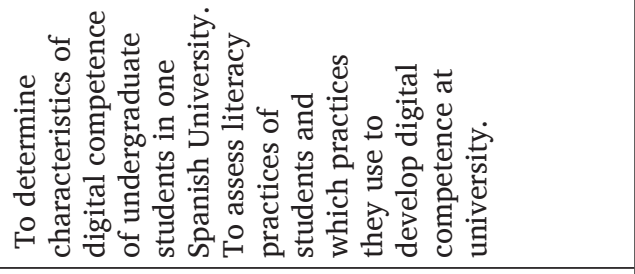 \\
\hline \multirow[t]{2}{*}{ 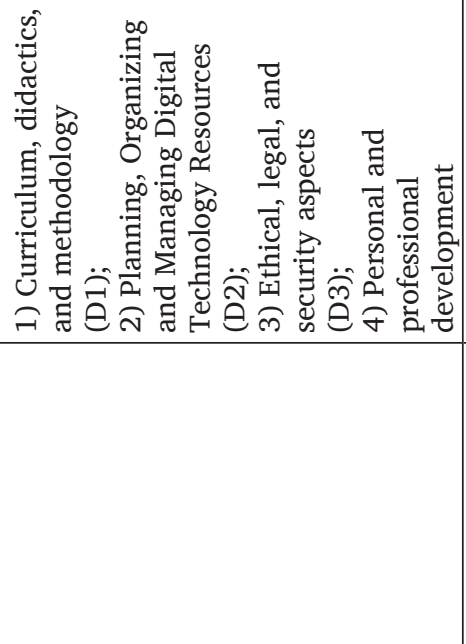 } & 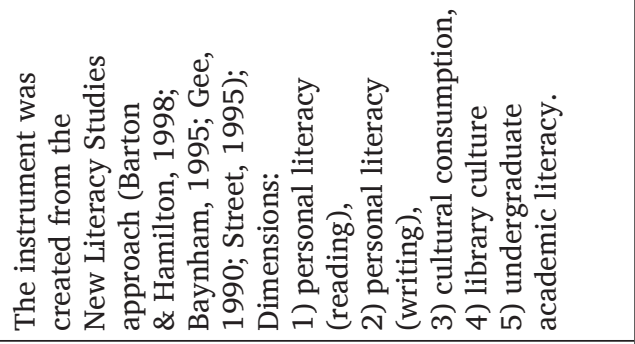 \\
\hline & 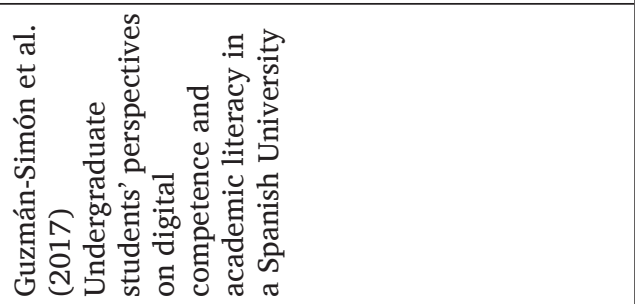 \\
\hline
\end{tabular}




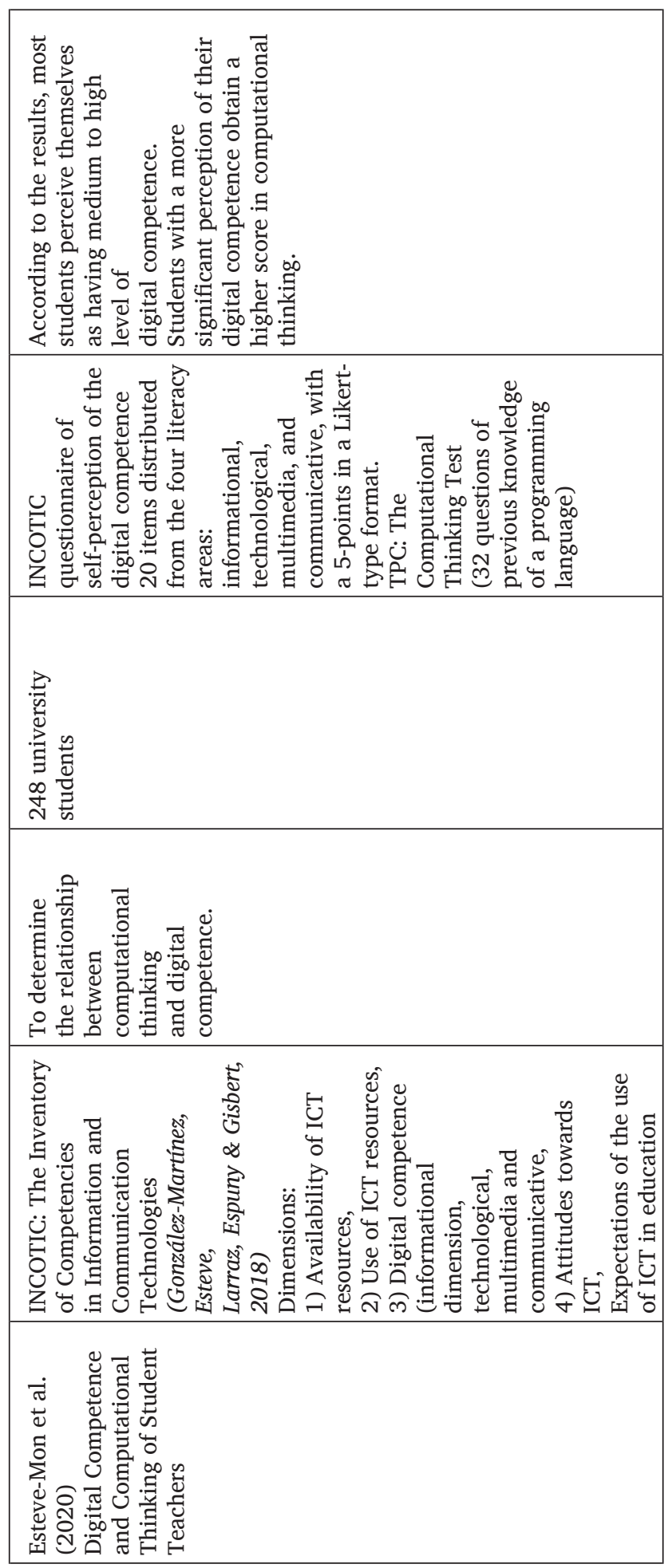


In some studies, the issues related to validity and reliability in terms of digital competence assessment instruments use were examined (Table 4).

Table 4. Validity and Reliability of Digital Competence assessment

\begin{tabular}{|c|c|c|}
\hline Author (Year) & Validity & Reliability \\
\hline $\begin{array}{l}\text { Crawford-Visbl et al. } \\
(2020)\end{array}$ & No information & No information \\
\hline Sciumbata (2020) & No information & No information \\
\hline Kuzminska et al. (2019) & No information & Cronbach's alpha \\
\hline Martzoukou et al. (2020) & No information & Cronbach's alpha \\
\hline He and Chang (2014) & $\begin{array}{l}\text { Confirmatory factor analysis and } \\
\text { partial least squares modelling }\end{array}$ & Cronbach's alpha \\
\hline Tejedor et al. (2020) & No information & Cronbach's alpha \\
\hline Esteve-Mon et al. (2020) & No information & No information \\
\hline $\begin{array}{l}\text { Guzmán-Simón et al. } \\
\text { (2017) }\end{array}$ & $\begin{array}{l}\text { Principal component analysis } \\
\text { (PCA) }\end{array}$ & Cronbach's alpha \\
\hline $\begin{array}{l}\text { Gutiérrez Porlán and } \\
\text { Sánchez Serrano (2016) }\end{array}$ & No information & No information \\
\hline Vázquez-Cano et al. (2017) & No information & $\begin{array}{l}\text { Cronbach's alpha } \\
\text { Guttman's }\end{array}$ \\
\hline Cote and Milliner (2016) & No information & No information \\
\hline Hajduova et al. (2020) & No information & Cronbach's alpha \\
\hline Silva et al. (2019) & $\begin{array}{l}\text { Expert judgment (nine experts } \\
\text { in the field of higher education } \\
\text { linked to ITT) }\end{array}$ & Cronbach's alpha \\
\hline
\end{tabular}

Cronbach's alpha was the most frequently used reliability coefficient. It was noted that four instruments reported neither validity nor reliability tests. Only three tools reported both validity and reliability tests.

\section{Discussion}

A scoping review was undertaken to describe digital competence assessment instruments to measure students' digital competence. The scoping review showed that most of the existing tests assess students' digital information searching communication and technical skills. In the review, most of the instruments were composed of several competence areas: information and data literacy, communication and collaboration, digital content creation, safety and problem-solving. The majority of the studies report on a designed self-assessment questionnaire comprising 
multiple-choice items and evaluation of digital competence. The present research helped to establish that the most commonly used framework was appeared to be the European DigComp framework for Citizens 2.0. (Vuorikari et al., 2016).

As part of the scoping review, the main key findings of the included studies were analysed. Some studies show that students tend to overestimate their digital competence and lack knowledge of fundamental topics (Gutiérrez Porlán \& Sánchez Serrano 2016; Sciumbata, 2020). The study conducted by Martzoukou and colleagues (2020) indicates that the development of digital competence is linked with their previous experiences in the digital environment in everyday life. For example, according to the research in Argentina, Colombia, Peru, and Venezuela, despite the high levels of digital literacy in communication and collaboration, students' competence in information and data literacy and digital content creation remained low (Crawford-Visbl et al., 2020).

In several research it was also found that men had higher levels of digital competence than women (He \& Milliner 2014; Crawford-Visbal et al., 2020). The results obtained by Esteve-Mon and colleagues (2020) show that digital competence is closely related to digital problem-solving (computational thinking), that is, students with higher digital competence scores had also higher digital problem - solving competency.

The study conducted by $\mathrm{He}$ and Milliner (2014) indicate that university students' digital competence has a positive association with students' digital informal learning, while students with a higher level of digital competence tend to get more involved in informal digital learning. Sciumbata (2020) established that 270 students participating had an excellent opinion of their digital skills most of them consider themselves to be good users and independent users in three out of five DigComp areas. However, when tested, significant gaps in their knowledge in all the areas were identified.

Our approach was not without limitations. First of all, the selection process, the inclusion, and exclusion criteria have influenced the outcomes of this scoping review. The exclusion of non-English studies further limits potentially relevant studies, which contain important and valuable information. This scoping review did not conduct a quality appraisal process of the research included. This may have influenced the interpretation of the research results. It is significant to note that, our search included three multidisciplinary databases, namely, ERIC, ProQuest, EBSCO). For further exploration of the issue, it is recommended to enlarge the number of databases by including other databases (i. e. Scopus, Web of Science). This scoping review could serve as the groundwork for a stricter systematic review. 


\section{Conclusions}

Nowadays, digital competence is gaining importance and represents a critical factor in every aspect of our lives. We have provided an overview of literature on digital competence assessment instruments in the field of higher education. The conclusion of our review is that research conducted at universities and colleges does not have a developed systematic approach to researching and assessing students' digital competencies. Several studies (Gutiérrez Porlán \& Sánchez Serrano 2016; Kuzminska et al., 2019) included in the report included such research participants in which students took part in short online study courses to acquire and improve digital skills, as a result of which students' existing digital skills were not systematically assessed, and students' existing digital skills were not taken into account. Some higher education institutions, such as National University of La Plata in Argentina, University of the Coast in Colombia, San Ignacio de Loyola University in Peru, Cecilio and Acosta Catholic University in Venezuela), conducted research on students' digital competences and focused mainly on the skills related to digital technologies, for example, which ICT and digital media that students use and integrate into the study process. The results obtained in the scoping review are significant in order to better assess students' future digital competences. Further research has to be focused specifically on high-validity digital competence assessment tools.

The digital competence assessment tools included in the review could be helpful for both universities and education policymakers for the development of digital competence assessment tools in higher education.

\section{References}

Arksey, H., \& O'Malley, L. (2005). Scoping studies: Towards a Methodological Framework. International Journal of Social Research Methodology, 8, 19-32. https://doi. org/10.1080/1364557032000119616

Barton, D. \& Hamilton, M. (1998). Local literacies. Reading and writing in one community. London \& New York: Routledge.

Bashir, S., \& Miyamoto, K. (2020). Digital Skills: Frameworks and Programs. World Bank, Washington, DC. Retrieved from: https://openknowledge.worldbank.org/ handle/10986/35080

Baynham, M. (1995). Literacy Practices: investigating literacy in social contexts. London and New York: Routledge.

Buckingham, D. (2015). Defining digital literacy - What do young people need to know about digital media? Nordic Journal of Digital Literacy, 4, 21-34. https://doi. org/10.18261/ISSN1891-943X-2006-04-03

Calvani, A., Cartelli, A., Fini, A., \& Ranieri M. (2008). Models and Instruments for Asessing Digital Competence at School. Journal of e-Learning and Knowledge Society, 4(3), 183-193. 
Calvani, A., Fini, A., Ranieri, M., \& Picci, P. (2012). Are young generations in secondary school digitally competent? A study on Italian teenagers. Computers \& Education, 58(2), 797-807.

Carretero, S., Vuorikari, R. \& Punie, Y. (2017). DigComp 2.1: The Digital Competence Framework for Citizens with eight proficiency levels and examples of use, EUR 28558 EN. https://doi.org/10.2760/38842

Cote, T., \& Milliner, B. (2016). Japanese university students' self-assessment and digital literacy test results. In S. Papadima-Sophocleous, L. Bradley \& S. Thouësny (Eds), CALL communities and culture - short papers from EUROCALL 2016 (pp. 125-131). Researchpublishing.net. https://doi.org/10.14705/rpnet.2016.eurocall2016.549

Crawford-Visbal, J. L., Crawford-Tirado, L., Ortiz-Záccaro, Z., \& Abalo, F. (2020). Assessment of Digital Competences in Communication Students across four Latin American Universities. Education in the Knowledge Society, 21, 14. https://doi. org/10.14201/eks.19112

Davis, K., Drey, N., \& Gould, D. (2009). What are scoping studies. A review of the nursing literature. International Journal of Nursing Studies, 46(10), 1380-1400. https:// doi.org/10.1016/j.ijnurstu.2009.02.010

Esteve-Mon, F. M., Llopis, A., \& Adell-Segura, J. (2020). Digital competence and computational thinking of student-teacher. International Journal of Emerging Technologies in Learning, 15(2). https://doi.org/10.3991/ijet.v15i02.11588

European Commission (2014). Digital Agenda for Europa. Retrieved from: https://europa. eu/european-union/file/1497/download_en?token=lTLHQiCI

European Commission (2021). Digital Education action Plan 2021-2027. Resetting education and training for the digital age. Retrieved from: https://ec.europa.eu/education/ sites/default/files/document-library-docs/deap-swd-sept2020_en.pdf

European Council (2018). Recommendation on key competences for lifelong learning. Retrieved from: https://eur-lex.europa.eu/legal-content/EN

Eurydice (2011). Key Data on Learning and Innovation through ICT at School in Europe 2011. European Commission. Retrieved from: http://eacea.ec.europa.eu/education/ eurydice/documents/key_data_series/129EN.pdf

Ferrari, A. (2012). Digital competence in practice: An analysis of frameworks. JRC Technical Reports. Institute for Prospective Technological Studies, European Union. https://doi. org/10.2791/82116

Ferrari, A., Neza, B., \& Punie, Y. (2014). DIGCOMP: A framework for developing and understanding digital competence in Europe. eLearning Papers, 38, 3-17. Retrieved from: https://publications.jrc.ec.europa.eu/repository/bitstream/JRC83167/1-na-26035-enn.pdf

Gee, J.P. (1990). Social Linguistics and Literacies: Ideology in Discourses. Bristol, PA: The Falmer Press.

Gilster, P. (1997). Digital literacy. New York, NY: John Wiley.

Gutiérrez Porlán, I., \& Serrano Sánchez, J.L. (2016). Evaluation and development of digital competence in future primary school teachers at the University of Murcia. Journal of New Approaches in Educational Research, 5(1), 51-56. https://doi.org/10.7821/ naer.2016.1.152

Guzmán-Simón, F., García-Jiménez, E. y López-Cobo, I. (2017). Undergraduate students' perspectives on digital competence and academic literacy in a Spanish University. Computers in Human Behavior, (74), 196-204. 
Hajduová, Z., Smol, K. Szajt, M., \& Bednárová, L. (2020). Digital Competences of Polish and Slovak Students Comparative Analysis in the Light of Empirical Research. Sustainability, 12(18), 7739. https://doi.org/10.3390/su12187739

He, T., \& Chang, Z. (2017). Digital informal learning among Chinese university students: the effects of digital competence and personal factors. International Journal of Educational Technology in Higher Education, 14 (44). https://doi.org/10.1186/s41239-017-0082-x

Ilomäki, L., Paavola, S., Lakkala, M., \& Kantosalo, A. (2016). Digital competence-An emergent boundary concept for policy and educational research. Education and Information Technologies, 21(3), 655-679. https://doi.org/10.1007/s10639-014-9346-4

International Telecommunication Union (2020). Measuring Digital Development: Facts and Figures 2020. Retrieved from: https://www.itu.int/en/ITU-D/Statistics/Documents/ facts/FactsFigures2020.pdf

Krumsvik, R. (2008). Situated learning and teachers' digital competence. Education and Information Technologies, 13, 279-290. https://doi.org/10.1007/s10639-008-9069-5

Kuzminska, O., Mazorchuk, M., Morze, N., Pavlenko, V., \& Prokhorov, A. (2019). Study of Digital Competence of the Students and Teachers in Ukraine. In: V. Ermolayev, M. Suárez-Figueroa, V. Yakovyna, H. Mayr, M. Nikitchenko, A. Spivakovsky (Eds.), Information and Communication Technologies in Education, Research, and Industrial Applications. ICTERI 2018. Communications in Computer and Information Science, vol. 1007. Springer, Cham. https://doi.org/10.1007/978-3-030-13929-2_8

Lázaro, J. L., \& Gisbert, M. (2015). Elaboració d'una rúbrica per avaluar la competència digital del docent. Universitas Tarraconensis. Revista de Ciències de l'Educació, 1(1), 48-63. doi:10.17345/ute.2015.1.648

Maderick, J.A., Zhang, S., Hartley, K., \& Marchand, G. (2016). Preservice Teachers, and Self-Assessing Digital Competence. Journal of Educational Computing Research, 54(3), 326-351. https://doi.org/10.1177/0735633115620432

Martzoukou, K., Fulton C., Kostagiolas, P., \& Lavranos, C. (2020). A study of higher education students' self-perceived digital competencies for learning and everyday life online participation. Journal of Documentation, 76(6) https://doi.org/10.1108/JD-032020-0041

Parvathamma, N., \& Pattar, D. (2013). Digital literacy among the student community in management institutes in Davangere District, Karnatake State, India. Annals of Library and Information Studies, 60, 159-166.

Redecker, C., \& Punie, Y. (2017) Digital Competence of Educators DigCompEdu; Publications Office of the European Union: Luxembourg.

Sciumbata, F. (2020). Students of humanities and digital skills: a survey on Italian university students. Umanistica Digitale, 4(8). https://doi.org/10.6092/issn.2532-8816/9877

Silva, J., Usart, M., \& Lazaro-Cantabrana, J. L. (2019). Teacher's digital competence among final year pedagogy students in Chile and Uruguay. Comunicar. Media Education Research Journal, 27, 33-43.

Slavova L., \& Garov, K. (2019). Increasing the digital competencies of students. Educational Matters, 76(1), 42-51.

Son, J., Robb, T.N., \& Charismiadji, I. (2011). Computer literacy and competency: a survey of Indonesian teachers of English as a foreign language. CALL-EJ, 12(1), 26-42.

Spante, M., Hashemi, S. S., Lundin, M., \& Algers, A. (2018). Digital competence and digital literacy in higher education research: Systematic review of concept use. Cogent Education, 5(1), 1-21. https://doi.org/10.1080/2331186X.2018.1519143 
Stopar, K., \& K., Bartol, T. (2019). Digital competences, computer skills and information literacy in secondary education: mapping and visualization of trends and concepts. Scientometrics 118(3), 479-498. https://doi.org/10.1007/s11192-018-2990-5

Street, B. (1995). Social literacies: Critical approaches to literacy in development, ethnography and education. London: Longman.

Tejedor, S., Cervi, L., Pérez-Escoda, A., \& Jumbo, F.T. (2020). Digital Literacy and Higher Education during Covid19 Lockdown: Spain, Italy, and Ecuador. Publications, MDPI, Open Access Journal, 8(4), 1-17 https://doi.org/10.3390/publications8040048

United Nations Educational, Scientific and Cultural Organization (2016). Education for people and planet: creating sustainable futures for all. Retrieved from: https://unesdoc. unesco.org/ark:/48223/pf0000245752

Vázquez-Cano, E. (2014). Mobile distance learning with smartphones and apps in higher education. Educational Sciences: Theory \& Practice, 14(4), 1-16. https://doi. org/10.12738/estp.2014.4.2012

Vázquez-Cano, E., Meneses, E. L., \& García-Garzón, E. (2017). Differences in basic digital competences between male and female university students of Social Sciences in Spain. International Journal of Educational Technology in Higher Education, 14, 1-16. https://doi.org/10.1186/s41239-017-0065-y

Vuorikari, R., Punie, Y., Carretero Gomez S., \& Van den Brande, G. (2016). DigComp 2.0: The Digital Competence Framework for Citizens. Update Phase 1: The Conceptual Reference Model. Luxembourg Publication Office of the European Union. EUR 27948 EN. https:// doi.org/10.2791/11517 